\title{
Features of Logistics Development in the BRICS countries
}

\author{
Vladimir Nekhoroshkov ${ }^{1}$, Alyona Aroshidze ${ }^{1}$, Peter Majercak ${ }^{2, *}$, and Peter Kurenkov ${ }^{3}$ \\ ${ }^{1}$ Siberian State Transport University, Novosibirsk, Russia \\ ${ }^{2}$ University of Zilina, FPEDAS, Department of Economics, Univerzitna 1, 01026 Zilina, Slovakia \\ ${ }^{3}$ Russian University of Transport (RUT-MIIT), Moscow, Russia
}

\begin{abstract}
Research background: Brazil, Russia, India, China, as well as South Africa (BRICS) have such economic potential that, according to the expert community, by 2050 they may become the dominant economies of the world. The aim of the scientific contribution is to analyze the BRICS countries about Logistics Performance Index (LPI).

Purpose of the article: Using the diagnostic matrix method, the analysis of the logistics development of the BRICS countries according to the estimates presented above makes it possible to characterize them according to each criterion, as well as to form a general characteristic. In addition, it is necessary to calculate the delta of the indicator for each criterion for each country for the selected study period.

Methods: We suggest using the Logistics Performance Index (LPI) and Emerging Market Logistics Index (EMLI) ratings as an information base for analyzing the logistics development of the BRICS countries. The LPI rating is calculated every two years by the World Bank, which, together with the University of Turku, developed it in 2007.

Findings \& Value added: As the analysis has shown, even within the framework of integration groups, such as the BRICS, the level of logistics development is quite different. The undisputed leader according to LPI is China, which bypasses other countries of the grouping not only in terms of the level of infrastructure development, in which some of the world's largest financial investments are made, but also in the quality of logistics services, customs and border clearance, organization of international transport, cargo tracking. timeliness of their delivery.
\end{abstract}

Keywords: Tumen; transport; logistics performance; transport modes

JEL Classification: J54;J55; J64

\footnotetext{
* Corresponding author: peter.majercak@fpedas.uniza.sk
} 


\section{Introduction}

BRICS is a group of rapidly developing countries with huge market potential - Brazil, Russia, India, South Africa. A distinctive feature of this integration association is the mechanism of interaction between countries, which in its content resembles a "club" mechanism through which the necessary decisions are made and transmitted. In recent decades, the industrial and financial potential of the BRICS countries has increased (Azam \& Haseeb, 2021; Çepni et al., 2020), which allows either already to occupy leading positions in the international markets for goods, services, capital, or gradually strive for this. According to forecasts, the national economies of the BRICS countries will show advanced development, thereby ensuring an increase in their global influence.

The past two decades have resulted in changes in the distribution of power and growth points in the global economy, reflected in the increasing economic power of emerging market economies. These countries include the BRICS countries, with China, India, Russia and Brazil being the key countries that provided significant growth in global GDP from 2000 to 2020. Of course, the factors that have contributed to the economic growth of the BRICS countries differ significantly. The growth of the economies of China and India was based on policies aimed at ensuring a high level of saving and accumulation rates, on the use of labor resources in manufacturing in the export sector (Samargandi \& Kutan, 2016). In Brazil and South Africa, social programs that stimulate final consumption of households have become the basis of economic growth. The economic recovery in Russia after the 90s was associated with the export of fuel and energy products and the use of a capacious domestic consumer market. As shown by the study by Adewale (2017), which was carried out according to statistical data for 1960-2016, the processes of industrialization and, accordingly, the increase in the industrial power of the BRICS countries are largely related to the policy of import substitution. Still, the factors of economic growth of the BRICS countries are quite strongly associated with energy resources, and therefore they are among the most volatile and unstable (Balcilar \& Usman, 2021; Li et al., 2021). On the other hand, the BRICS countries, albeit with varying degrees of intensity, are included in the fourth industrial revolution (Chan \& Daim, 2012; Haji, 2021; Hu, 2021), thus, the digitalization of logistics approaches is observed even in the energy sector (Barykin et al., 2021). In general, based on modern requirements, digitalization processes have been activated in various sectors, which is especially important for the transport and logistics systems of countries (Kampf et al., 2016).

It is safe to say that the common factor of economic development for the BRICS countries is precisely logistics. Almost any foreign trade transaction begins and ends with transport and logistics operations (Gani, 2017), while these operations also ensure the connectivity of industries and regions within the country. The logistics development of countries is a reflection of the effectiveness of a systematic approach to business problems. Of course, the logistics industry of any country is subject to constant transformations, logistics companies must constantly monitor and adapt to trends, providing themselves with a competitive edge in the market. Logistics is now even more related to customer focus, environmental protection, constant innovation, especially in the field of information technology (Hammes et al., 2020; Lan et al., 2020; Tavasszy, 2020). The successes of the logistics industry, achieved thanks to the created conditions, determine the level of national logistics development of the BRICS countries. In turn, this is a factor not only for the development of production, increasing the efficiency of organizing material and information flows, but also for ensuring intensive economic growth of the BRICS countries based on the use of limited resources. In this regard, the purpose of this article is to analyze the logistics development of the BRICS countries according to the rating criteria recognized all over the world, as well as to form, on the basis of this analysis, the characteristics of the countries. This will make it possible to identify bottlenecks and potential growth points of the BRICS countries from the 
standpoint of the development of logistics as a factor in further building up their economic power.

\section{Materials and Methods}

We suggest using the Logistics Performance Index (LPI) and Emerging Market Logistics Index (EMLI) ratings as an information base for analyzing the logistics development of the BRICS countries. The LPI rating is calculated every two years by the World Bank, which, together with the University of Turku, developed it in 2007. To compile the final rating (The World Bank, 2021), an assessment is carried out according to such criteria as customs, infrastructure, international shipments, logistics competence, tracking and tracing, timeliness. The EMLI rating (Agility, 2021) was developed by the Transport Intelligence Research Institute in 2010 and is based on such criteria as domestic logistics opportunities, international logistics opportunities, business fundamentals (Majercak et al., 2013).

Using the diagnostic matrix method, the analysis of the logistics development of the BRICS countries according to the estimates presented above makes it possible to characterize them according to each criterion, as well as to form a general characteristic. To do this, for each criterion, it is necessary to calculate the average value of the indicator among all countries of the rating and among the BRICS countries. In addition, it is necessary to calculate the delta of the indicator for each criterion for each country for the selected study period. Based on the combination of these presented views, several images are presented, which include the group data. So, if a country, according to a specific criterion for assessing logistics development, is characterized by an indicator above the average (within all countries and/or BRICS countries), while there is a positive trend, then the country is the undisputed leader. If, at the level of the indicator above the average, its value has negative dynamics, then it refers to the characteristics of losing development potential according to this specific criterion. A country that shows a low indicator according to the criterion (below average), but with positive dynamics, can be considered as catching up. In the case of negative dynamics of the indicator, the level of which is already less than the average, the country shows as lagging behind.

These characteristics are awarded to the BRICS countries according to all criteria of the LPI index, which allows identifying points of growth and problems of logistics development. In addition, the general characteristics of countries are formed on the basis of a diagnostic matrix containing particular characteristics for two ratings - LPI and EMLI.

\section{Results and Discussion}

According to the current rating (2018), China is characterized by the highest level of logistics development among the BRICS countries (Figure 1). His score is 3.61, which places him in twenty-sixth place. In the previous rating, experts rated the logistics development at 3.66 points, while this corresponded to the twenty-seventh place. South Africa is on the thirtythird position, which, against the background of a decrease in the indicator from 3.78 to 3.38 , moved from twenty to thirty-third place. Also, logistics in India is rated worse by experts: if earlier it was awarded 3.42 points (thirty-fifth place), but at the moment it is estimated only at 3.18 points (forty-fourth place). Russia, on the contrary, improved its logistic characteristics, having risen from ninety-ninth to seventy-fifth place, which in terms of points corresponds to the next change - from 2.57 to 2.76. Brazil's index fell from 3.09 to 2.99, but this led to a slight change in positions - from fifty-fifth to fifty-sixth place. 


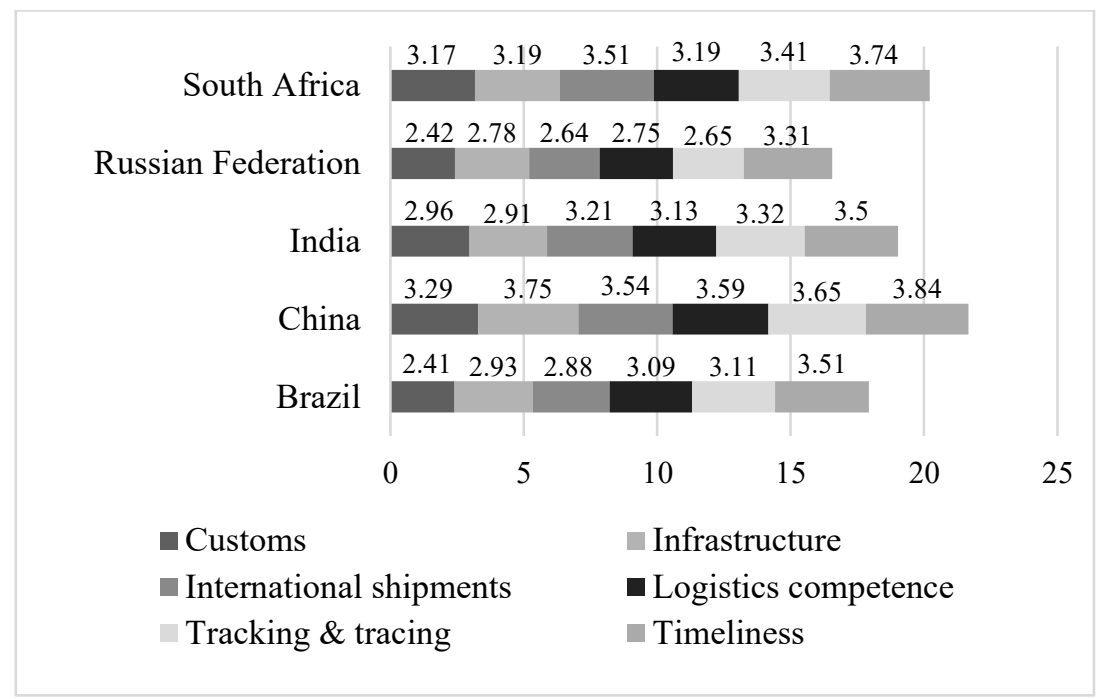

Figure 1. The current positions of the BRICS countries according to the LPI rating

Source: Logistics Performance Index

According to the criterion of customs and border clearance (Table 1), China is the leader among the BRICS countries, whose indicator in the current rating is 3.29. South Africa is close behind at 3.17. It should be noted that in the first case there was a decrease in the indicator by 0.03 points, but this did not lead to a change in rank positions; in the second case, a decrease in the indicator by 0.43 points led to the thirty-fourth place instead of the eighteenth. Also, there was a deterioration in the quality of customs and border clearance in India, which was reflected in a decrease in the corresponding indicator from 3.17 (thirtyeighth place) to 2.96 (forty-eighth place). Note that the same value of the indicator in the current rating corresponds to the thirty-fourth place (it was mentioned earlier about South Africa). The indicators of customs clearance conditions in Russia and Brazil are almost identical, but slightly ahead of the first -2.42 , which corresponds to ninety-seventh place, and 2.4, that is, one hundred and second place. At the same time, if Russia significantly improved its indicators, which previously amounted to 2.01 and one hundred and forty-first place, then Brazil earlier with an indicator of 2.76 took sixty-second place. In accordance with the constructed diagnostic matrix, within all countries of the ranking, Russia is among the leading regions, and Brazil, China, India and South Africa form a group of regions losing potential. Among the BRICS, in terms of customs and border clearance, Russia can be described as a catching-up region, the leader is South Africa, China and India are losing their potential, and Brazil is lagging behind other participating countries.

Table 1. Diagnostic matrix for the "customs" indicator

\begin{tabular}{|l|c|c|c|c|}
\hline \multirow{2}{*}{$\begin{array}{l}\text { Dynamics of } \\
\text { points }\end{array}$} & \multicolumn{4}{|c|}{ Points } \\
\cline { 2 - 5 } & \multicolumn{2}{|c|}{ All countries } & \multicolumn{2}{|c|}{ BRICS } \\
\cline { 2 - 5 } & Below the average & Above the average & Below the average & Above the average \\
\hline Growth & - & Russia & Russia & South Africa \\
\hline Reduction & - & $\begin{array}{c}\text { Brazil, China, } \\
\text { India, South } \\
\text { Africa }\end{array}$ & Brazil & China, India \\
\hline
\end{tabular}

Source: the authors' calculations based on the Logistics Performance Index data 
The quality of infrastructure (Table 2) ranked China in first place among the BRICS countries: the point score was 3.75 , which ensured it the twentieth place in the overall rating. Interestingly, in the previous ranking, with an identical assessment, China took only twentythird place. The development of infrastructure in South Africa was estimated by experts at 3.19 points (thirty-sixth place), which is 0.59 points lower than in the previous rating (twentyfirst place). Brazil (2.93) and India (2.91), which are in fiftieth and fifty-second places, are significantly lagging behind in terms of infrastructure indicators. In the previous rating, the positions of these countries were significantly higher - forty-seventh (3.11) and thirty-sixth (3.34). According to the criterion under consideration, Russia is in sixty-first place with a point estimate of 2.78, although in the previous rating the value of the indicator was 2.43, which corresponded only to ninety-fourth place. Most of the BRICS countries, namely India, Brazil and South Africa, can be characterized as lagging among all the countries in the ranking. China's indicators allow us to consider it as a leading region in infrastructure development, Russia as a catching-up region. Within the BRICS, the characteristics of the countries have not changed, with the exception of South Africa, which, according to the diagnostic matrix, is in the group of regions losing potential (Nedeliakova et al., 2014b).

Table 2. Diagnostic matrix for the "infrastructure" indicator

\begin{tabular}{|l|c|c|c|c|}
\hline \multirow{2}{*}{$\begin{array}{l}\text { Dynamics of } \\
\text { points }\end{array}$} & \multicolumn{4}{|c|}{ Points } \\
\cline { 2 - 5 } & Below the average & Above the average & Below the average & Above the average \\
\hline Growth & Russia & China & Russia & China \\
\hline Reduction & $\begin{array}{l}\text { India, Brazil, } \\
\text { South Africa }\end{array}$ & - & Brazil, India, & South Africa \\
\hline
\end{tabular}

Source: the authors' calculations based on the Logistics Performance Index data

As in the previous criterion, the leader among the BRICS countries in terms of the level of organization of international transport (Table 3 ) is China, which ranks eighteenth with a score of 3.54. In the previous rating, the value of the indicator was noticeably higher, amounting to 3.7, which corresponded to the twelfth place. South Africa is slightly behind in scores, which is in twenty-second place (3.51). In the previous rating, the country was in twenty-third place, although the value of the indicator was significantly higher -3.62 . In the forty-fourth place in the ranking with 3.21 points is India, which was previously in thirtyninth place with a score of 3.36 points.

All the countries under consideration, except for Russia, among all the countries of the rating can be attributed to the regions that are losing their potential. Russia, however, should be characterized as a leading region in terms of international traffic. Within the BRICS, the distribution is somewhat different: Russia is a catching-up region, Brazil is lagging behind, and China, India, South Africa are in the group of regions losing potential.

Table 3. Diagnostic matrix for the "international shipments" indicator

\begin{tabular}{|l|c|c|c|c|}
\hline \multirow{2}{*}{$\begin{array}{l}\text { Dynamics of } \\
\text { points }\end{array}$} & \multicolumn{3}{|c|}{ Points } \\
\cline { 2 - 5 } & \multicolumn{2}{|c|}{ All countries } & BRICS \\
\cline { 2 - 5 } & Below the average & Above the average & Below the average & Above the average \\
\hline Growth & - & Russia & Russia & - \\
\hline Reduction & - & $\begin{array}{c}\text { Brazil, China, } \\
\text { India, South } \\
\text { Africa }\end{array}$ & Brazil & $\begin{array}{c}\text { China, India, } \\
\text { South Africa }\end{array}$ \\
\cline { 2 - 5 } & & & & South \\
\hline
\end{tabular}

Source: the authors' calculations based on the Logistics Performance Index data

Based on the two previous criteria, it is quite logical that the leader among the BRICS countries in terms of the quality of logistics services (Table 4) is China, ranking twenty- 
seventh in the ranking with 3.59 points. In the previous rating, he was in the same position, but with a slightly higher indicator - 3.62. South Africa's score has dropped quite significantly - from 3.75 to 3.19 , bringing its position down by sixteen points to thirty-ninth place. India's logistics services quality rating also dropped from 3.39 to 3.13 , with a deterioration in its position in the ranking from thirty-second to forty-second. Brazil strengthened its position in the ranking, having risen from fiftieth to forty-sixth place, although the score increased significantly - by 0.47 points to 3.59 . Within the framework of the overall rating, the BRICS countries belong to the regions that are losing potential in terms of the level of logistics development. Within the group, a similar characteristic applies to China and South Africa, while Brazil, India and Russia are representatives of the lagging regions.

Table 4. Diagnostic matrix for the "logistics competence" indicator

\begin{tabular}{|l|c|c|c|c|}
\hline \multirow{2}{*}{$\begin{array}{l}\text { Dynamics of } \\
\text { points }\end{array}$} & \multicolumn{4}{|c|}{ Points } \\
\cline { 2 - 5 } & \multicolumn{2}{|c|}{ All countries } & \multicolumn{2}{c|}{ BRICS } \\
\cline { 2 - 5 } & Below the average & Above the average & Below the average & Above the average \\
\hline Rrowth & - & - & - & - \\
\hline Reduction & - & $\begin{array}{c}\text { Brazil, China, } \\
\text { India, Russia, } \\
\text { South Africa }\end{array}$ & $\begin{array}{c}\text { Brazil, India, } \\
\text { Russia }\end{array}$ & $\begin{array}{c}\text { China, South } \\
\text { Africa }\end{array}$ \\
\hline
\end{tabular}

Source: the authors' calculations based on the Logistics Performance Index data

Leadership among the BRICS countries in terms of tracking the passage of goods (Table 5 ) belongs to China, whose indicator is 3.65 , which corresponds to the twenty-seventh place. Interestingly, earlier the score was 0.03 points higher, but this corresponded to only twentyeighth place. A significant deterioration in the position was observed in South Africa - from seventeenth place (3.92) to thirty-fifth (3.41). India is on the thirty-eighth place of the rating, its indicator has significantly deteriorated by 0.2 points to 3.32 . She was previously ranked thirty-third. In the overall rating, Russia is characterized as a lagging region, while other BRICS countries are losing their potential. Within the grouping, Brazil, India, Russia correspond to lagging regions, China and South Africa - losing their potential according to the criterion under consideration.

Table 5. Diagnostic matrix for the "tracking and tracing" indicator

\begin{tabular}{|l|c|c|c|c|}
\hline \multirow{2}{*}{$\begin{array}{l}\text { Dynamics of } \\
\text { points }\end{array}$} & \multicolumn{3}{|c|}{ Points } \\
\cline { 2 - 5 } Growth & - & - & \multicolumn{2}{c|}{ BRICS countries } \\
\cline { 2 - 5 } & Below the average & Above the average & Below the average & Above the average \\
\hline Reduction & Russia & $\begin{array}{c}\text { Brazil, China, } \\
\text { India, South } \\
\text { Africa }\end{array}$ & $\begin{array}{c}\text { Brazil, India } \\
\text { Russia }\end{array}$ & $\begin{array}{c}\text { China, South } \\
\text { Africa }\end{array}$ \\
\hline
\end{tabular}

Source: the authors' calculations based on the Logistics Performance Index data

Remaining the leader among the BRICS countries in terms of the timeliness of deliveries (Table 6), China ranks twenty-seventh (3.84), which is six positions worse than in the previous rating (3.9). The indices for Brazil and India are practically identical - 3.51 and 3.5, which corresponds to fifty-first and fifty-second places. At the same time, in the previous rating, the country took the twenty-fourth place, and the point score was 4.02. Russia has significantly improved its position, moving forward from eighty-seventh to sixty-sixth place, increasing the indicator from 3.15 to 3.31 . This allowed Russia, within the framework of the entire rating, to become one of the leading regions, while all the other countries under consideration are classified as losing their potential in terms of timely deliveries. On the other 
hand, among the BRICS countries, Russia can be described as a catching-up region, Brazil as a lagging region, China, India, South Africa - as losing potential (Nedeliakova et al., 2014a).

Table 6. Diagnostic matrix for the "timeliness" indicator

\begin{tabular}{|c|c|c|c|c|}
\hline \multirow{3}{*}{$\begin{array}{l}\text { Dynamics of } \\
\text { points }\end{array}$} & \multicolumn{4}{|c|}{ Points } \\
\hline & \multicolumn{2}{|c|}{ All countries } & \multicolumn{2}{|c|}{ BRICS } \\
\hline & Below the average & Above the average & Below the average & Above the average \\
\hline Growth & - & Russia & Russia & - \\
\hline Reduction & - & $\begin{array}{c}\text { Brazil, China, } \\
\text { India, South } \\
\text { Africa }\end{array}$ & Brazil & $\begin{array}{l}\text { China, India, } \\
\text { South Africa }\end{array}$ \\
\hline
\end{tabular}

Source: the authors' calculations based on the Logistics Performance Index data

The development of logistics, obviously, involves serious investments, which, as a rule, are carried out by the largest logistics providers. These logistics companies have already achieved a strong position in the market, have serious management experience and, with the aim of expanding their influence, entering new markets. If these companies are already in a certain foreign market, investments in the development of logistics can be justified by the goals set for the company itself. In any case, the development of logistics depends not only on national programs, which, first of all, cover the transport infrastructure, investments of domestic logistics operators and businesses, but also on foreign investments.

According to the EMLI rating (Table 7) among the BRICS countries and in general among the developing economies, China has the highest degree of attractiveness of the logistics market for foreign investment. In the current rating it was at the level of 8.86 , which is slightly lower than last year's points - 8.9. The level of development of domestic logistics opportunities was estimated by experts at 8.81 , which is also lower than the previous indicator, which was 8.87. A similar criterion, but of an international scale, from the standpoint of China's capabilities, is estimated at 9.72 points against 9.75 in the previous rating. The indicator on the criterion of business fundamentals, although it secured China first place, was the lowest of all - 7.14 (previous 7.17).

Table 6. The current positions of the BRICS countries according to the EMLI rating

\begin{tabular}{|l|c|c|c|c|c|}
\hline \multicolumn{1}{|c|}{ Country } & Rank & Overall scores & $\begin{array}{c}\text { Domestic } \\
\text { logistics } \\
\text { opportunities }\end{array}$ & $\begin{array}{c}\text { International } \\
\text { logistics } \\
\text { opportunities }\end{array}$ & $\begin{array}{c}\text { Business } \\
\text { fundamentals }\end{array}$ \\
\hline China & 1 & 8,86 & 8,81 & 9,72 & 7,14 \\
\hline India & 2 & 7,33 & 8,19 & 7,16 & 5,95 \\
\hline Russia & 13 & 5,4 & 5,13 & 5,56 & 5,64 \\
\hline Brazil & 16 & 5,21 & 5,34 & 5,59 & 4,15 \\
\hline South Africa & 24 & 4,9 & 4,6 & 4,97 & 5,38 \\
\hline
\end{tabular}

Source: the authors' calculations based on the Emerging Market Logistics Index data

India is in second place in the EMLI ranking, while lagging behind the leader. The final figure is 8.86 , which is 0.06 points lower than the previous one. The most developed criterion is domestic logistics opportunities, the score for which is at the level of 8.19, having increased by 9.14 points in comparison with the previous year. International logistics opportunities were rated by experts at 7.16 points compared to the previous 7.54 points. In terms of business fundamentals, India strengthened its position, showing an increase from 5.7 to 5.95 points. Next in the EMLI ranking among the BRICS countries is Russia, which with 5.4 points takes the thirteenth place. Interestingly, according to the results of the last rating, the point score was 5.46, which also corresponded to the thirteenth place. Unlike previous countries, Russia 
has the strongest positions in terms of business fundamentals, with an increase of 0.19 points to 5.64 .

The final figure for South Africa showed an increase of 0.03 points to 4.9 , but despite this, it moved in the ranking from twenty-third to twenty-fourth place. A decrease in the score was observed only for the criterion of domestic logistics opportunities - from 4.64 to 4.6. The increase in international logistics capabilities amounted to 0.01 points to 4.97 . The positions on the business fundamentals criterion improved by 0.22 points to 5.38 .

In general, it should be noted that the lag behind the leader in terms of the final indicator is almost 4.0 points. The largest range of maximum and minimum values was recorded according to the criterion of international logistics opportunities, namely 4.75 points. The smallest gap between the leader and the outsider of the rating of the BRICS countries was recorded according to the criterion of business fundamentals - 2.99. In addition, to a greater extent, the development of the logistics market is associated with international opportunities.

Returning to our proposed characteristic of the BRICS countries in terms of the ratio of the obtained indicator to the average, as well as to the nature of its changes, Table 8 shows the diagnostic matrix for the two considered ratings. So, only the characteristics of China and Brazil are the same. Brazil, in accordance with similar ratios, is a lagging country within the BRICS in terms of its logistics development. South Africa, according to the EMLI index, can be characterized as a catching-up region, and according to the LPI index, as losing the potential for logistics development within the BRICS. The most significant differences are observed in the characteristics of India and Russia. On the one hand, India belongs to a region that is losing potential, while according to the LPI index it is a lagging region. Russia, being a lagging region according to the EMLI index, is characterized as catching up in its logistics development.

Table 6. Diagnostic matrix of logistics development of the BRICS countries

\begin{tabular}{|l|c|c|c|c|}
\hline \multirow{2}{*}{$\begin{array}{l}\text { Pogistics } \\
\text { Index }\end{array}$} & \multicolumn{4}{|c|}{ Emerging Market Logistics Index } \\
\cline { 2 - 5 } & Leaders & Losing potential & Catch-up & Lagging \\
\hline Leaders & - & - & - & - \\
\hline Losing potential & - & China & South Africa & - \\
\hline Catch-up & - & - & - & Russia \\
\hline Lagging & - & India & - & Brazil \\
\hline
\end{tabular}

Source: the authors' calculations based on the Logistics Performance and Emerging Market Logistics Index data

At the present stage, the logistic development of countries, especially the BRICS, which are believed to largely determine the trends of the world economy, depends not only on the level of organization of internal logistic processes and international opportunities, but also on the degree of digitalization of interaction. The digital logistics platform of countries can become not only a tool for uniting players in the logistics market, but also be used as a service platform, verification of counterparties, providing access to the necessary regulatory legal acts, information bases, etc. Therefore, digital logistics platforms are integrators of business processes, which use end-to-end technologies, thereby improving the quality of logistics services and reducing their costs. An example of such a platform is the national logistics platform LOGINK (China). This platform for uniting participants in the logistics process through Internet technologies takes into account various types of data: the state of the infrastructure, regulations, information on transportation options, mode of transport and delivery methods, participants' credit data, information on movement in real time. LOGINK unites all participants in the logistics chain, from operators to terminals, ports and the actual consumers of logistics services. Within BRICS, there is the New Silk Road BRICS platform, which is a worldwide freight exchange and global trading platform. A distinctive feature of 
this platform is support by high-level structures, namely the BRICS Transport Association, the BRICS Energy Association, the SCO Business Club, the IT Association, Blockchain and BRICS Cryptocurrencies. The key goal of the New Silk Road BRICS digital platform project is the digitalization of the entire supply chain.

\section{Conclusion}

Modern conditions have firmly identified logistics as one of the key factors influencing the efficiency of production and trade processes. Moreover, logistics can be considered without any doubt as a powerful and effective tool for ensuring competitive advantages in the product sales market. At the same time, the level of national development of logistics should contribute to the rapid adaptation of manufacturers to the changing demand for products and the rapidly changing market environment. In the context of globalization, the exit of supply chains far beyond national borders is an integral sign of the development of the world economy, and accordingly, logistics is also taking on a global character. At the same time, if international logistics can be viewed as simply crossing borders in supply chains, then global logistics is already a strategy for creating certain logistics schemes that connect business structures belonging to different countries around the world. However, the alignment of these macrological schemes is based on national logistics systems, which is why logistics often faces a number of problems (Jerabek et al, 2016).

As the analysis has shown, even within the framework of integration groups, such as the BRICS, the level of logistics development is quite different. The undisputed leader according to LPI is China, which bypasses other countries of the grouping not only in terms of the level of infrastructure development, in which some of the world's largest financial investments are made, but also in the quality of logistics services, customs and border clearance, organization of international transport, cargo tracking. timeliness of their delivery. However, despite the rather high indicators according to these criteria, even among all countries, for the most part they are characterized by negative dynamics. This trend is typical for almost all BRICS countries, the only exception is Russia. The level of logistics development by all criteria, with the exception of the quality of logistics services, showed gradual progress, although this is often not noticeable in the distribution of rank positions.

China is the undisputed leader in the BRICS in terms of the level of logistics development in accordance with EMLI estimates, but in this case, there is a deterioration in expert assessments. The decline in indicators is typical for all countries by almost all criteria, but this is especially noticeable with respect to international logistics capabilities. Interestingly, only Russia and South Africa have their most powerful business fundamentals. At the same time, it is obvious that within the BRICS, the development of logistics is largely associated with the international capabilities of countries.

In general, the analysis carried out allows us to fairly accurately reflect the level of logistics development of the BRICS countries, as evidenced by a noticeable correlation relationship between the final indices of the two ratings considered. It can be concluded that the digitalization of logistics activities should become the main one for the national development of logistics within the BRICS and the elimination of barriers to the global logistics strategy. A comprehensive solution in this context is digital logistics platforms, examples of the formation of which exist not only in individual countries, but also within the entire integration group. 


\section{Acknowledgements}

This paper is output of scientific project $057 Z ̌ U-4 / 2021$ Innovative approaches in the system of teaching logistics with a focus on the creation of logistics networks in pandemic conditions.

\section{References}

1. Adewale, A. R. (2017). Import substitution industrialisation and economic growth Evidence from the group of BRICS countries. Future Business Journal, 3(2), 138-158.

2. Agility (2021). Emerging Market Logistics Index. Available at: https://logisticsinsights.agility.com/emerging-markets-logistics-index/overview/. [June $12,2021]$.

3. Azam, M., \& Haseeb, M. (2021). Determinants of foreign direct investment in BRICSdoes renewable and non-renewable energy matter? Energy Strategy Reviews, 35, 100638 .

4. Balcilar, M., \& Usman, O. (2021). Exchange rate and oil price pass-through in the BRICS countries: Evidence from the spillover index and rolling-sample analysis. Energy, 229, 120666.

5. Barykin, S., Kapustina, I., Kalinina, O., Kozlova, N., Ivanova, E., Borodina, K., \& Yadykin, V. (2021). Digital Logistics Approach to Energy Service Socio-economic Mechanisms. Transportation Research Procedia, 54, 617-627.

6. Çepni, O., Gül, S., Hacıhasanoğlu, Y. S., \& Yılmaz, M. H. (2020). Global uncertainties and portfolio flow dynamics of the BRICS countries. Research in International Business and Finance, 54, 101277.

7. Chan, L., \& Daim, T. (2012). Exploring the impact of technology foresight studies on innovation: Case of BRIC countries. Futures, 44(6), 618-630.

8. Gani, A. (2017). The Logistics Performance Effect in International Trade. The Asian Journal of Shipping and Logistics, 33(4), 279-288.

9. Haji, K. (2021). E-commerce development in rural and remote areas of BRICS countries. Journal of Integrative Agriculture, 20(4), 979-997.

10. Hammes, G., De Souza, E. D., Rodriguez, C. M. T., Millan, R. H. R., \& Herazo, J. C. M. (2020). Evaluation of the reverse logistics performance in civil construction. Journal of Cleaner Production, 248, 119212.

11. Hu, G. (2021). Is knowledge spillover from human capital investment a catalyst for technological innovation? The curious case of fourth industrial revolution in BRICS economies. Technological Forecasting and Social Change, 162, 120327.

12. Jerabek, K., Majercak, P., Kliestik, T., \& Valaskova, K. (2016). Application of Clark and Wright's Savings Algorithm Model to Solve Routing Problem in Supply Logistics. Nase more, 63(3), 115-119.

13. Kampf, R., Majercak, P., Svagr, P. (2016). Application of break-even point analysis. Nase more, 63 (3), 126-128.

14. Lan, S., Tseng, M., Yang, C., \& Huisingh, D. (2020). Trends in sustainable logistics in major cities in China. Science of The Total Environment, 712, 136381.

15. Li, Y., Huang, J., Gao, W., \& Zhang, H. (2021). Analyzing the time-frequency connectedness among oil, gold prices and BRICS geopolitical risks. Resources Policy, 73,102134 . 
16. Majercak, P., Kliestik, T., Masárová, G., Buc, D., \& Majercakova, E. (2013). System Approach of Logistic Costs Optimization Solution in Supply Chain. Nase more, 60 (56), 95-98.

17. Nedeliakova, E., Sekulova, J., Nedeliak, J., \& Majercak, P. (2014a). Safety of Level Crossings from Society-Wide Perspective. Transport Means, Lithuana.

18. Nedeliakova, E., Nedeliak, I., \& Majercak, P. (2014b). Research of Services Quality after the End of Transportation in Railway Freight Transport. $2^{\text {nd }}$ International conference on management innovation and business innovation (ICMIBI).

19. Samargandi, N., \& Kutan, A. M. (2016). Private credit spillovers and economic growth: Evidence from BRICS countries. Journal of International Financial Markets, Institutions and Money, 44, 56-84.

20. Tavasszy, L. A. (2020). Predicting the effects of logistics innovations on freight systems: Directions for research. Transport Policy, 86, A1-A6.

21. The World Bank (2021). Logistics Performance Index. Available at: https://lpi.worldbank.org/international/global access. [June 12, 2021]. 